\title{
Multifaceted interplay between lipophilicity, protein interaction and luminescence parameters of non-intercalative ruthenium(II) polypyridyl complexes controlling cellular imaging and cytotoxic properties
}

\author{
Olga Mazuryk $\cdot$ Katarzyna Magiera $\cdot$ \\ Barbara Rys $\cdot$ Franck Suzenet $\cdot$ Claudine Kieda \\ Małgorzata Brindell
}

Received: 2 June 2014/ Accepted: 12 August 2014/Published online: 26 August 2014

(C) The Author(s) 2014. This article is published with open access at Springerlink.com

\begin{abstract}
Here, we examine the photophysical properties of five ruthenium(II) complexes comprising two 4,7diphenyl-1,10-phenanthroline (dip) ligands and functionalized bipyridine $\left(\mathrm{R}_{1}\right.$ bpy- $\mathrm{R}_{2}$, where $\mathrm{R}_{1}=\mathrm{H}$ or $\mathrm{CH}_{3}$, $\mathrm{R}_{2}=\mathrm{H}, \mathrm{CH}_{3}, \mathrm{COO}^{-}, 4-[3$-(2-nitro-1H-imidazol-1-yl)propyl] or 1,3-dicyclohexyl-1-carbonyl-urea) towards development of luminescence probes for cellular imaging. These complexes have been shown to interact with albumin and the formed adducts exhibited up to eightfold increase in the luminescence quantum yield as well as the average lifetime of emission. It was demonstrated that they cannot bind to DNA through the intercalation mode and its luminescence in the presence of DNA is quenching. Cell viability experiments indicated that all complexes possess significant dose-dependent cytotoxicity (with $\mathrm{IC}_{50} 5-19 \mu \mathrm{M}$ ) on 4T1 breast cancer cell line and their anti-proliferative
\end{abstract}

Electronic supplementary material The online version of this article (doi:10.1007/s00775-014-1187-5) contains supplementary material, which is available to authorized users.

O. Mazuryk · K. Magiera $\cdot$ M. Brindell $(\bowtie)$

Department of Inorganic Chemistry, Faculty of Chemistry, Jagiellonian University, Ingardena 3, 30-060 Krakow, Poland e-mail: brindell@chemia.uj.edu.pl

K. Magiera · B. Rys

Department of Organic Chemistry, Faculty of Chemistry, Jagiellonian University, Ingardena 3, 30-060 Krakow, Poland

F. Suzenet

Institute of Organic and Analytical Chemistry, University of Orléans, UMR-CNRS 7311, rue de Chartres, BP 6759,

45067 Orléans cedex 2, France

C. Kieda

Centre de Biophysique moléculaire, CNRS, rue Charles Sadron, 45071 Orléans cedex 2, France activity correlates very well with their lipophilicity. Cellular uptake was studied by measuring the ruthenium content in cells using ICP-MS technique. As expected, the better uptake is directly related to higher lipophilicity of doubly charged ruthenium complexes while uptake of monocationic one is much lower in spite of the highest lipophilicity. Additionally staining properties were assessed using flow cytometry and fluorescence microscopy. These experiments showed that complex with 1,3-dicyclohexyl-1-carbonyl-urea substituent exhibits the best staining properties in spite of the lowest luminescence quantum yield in buffered solution ( $\mathrm{pH}$ 7.4). Our results point out that both the imaging and cytotoxic properties of the studied ruthenium complexes are strongly influence by the level of internalization and protein interaction.

Keywords Ruthenium polypyridyl complexes . Cytotoxicity - Optical imaging · Luminescence $\cdot$ Protein binding

\section{Introduction}

Ruthenium polypyridyl complexes have been studied as structure- and site-specific DNA probes and nucleus imaging agents in biological systems, since the interaction of $\left[\mathrm{Ru}(\mathrm{bpy})_{2}(\mathrm{dppz})\right]^{2+}$ (bpy: 2,2'-bipyridine, dppz: dipyrido[3,2-a: $2^{\prime} 3^{\prime}$-c]phenazine) complexes with DNA through intercalation revealed significant enhancement of the luminescent intensity, the so-called "light switch" effect $[1,2]$. Despite high DNA-binding constant $\left(>10^{6} \mathrm{M}^{-1}\right)[3$, 4], ruthenium complexes of the type $\left[\mathrm{RuL}_{2}(\mathrm{dppz})\right]^{2+}$ ( $\mathrm{L}=$ bpy, phen: phenanthroline, dip: 4,7-diphenyl-1,10phenanthroline) demonstrate cellular internalization (staining of cytoplasm) with limited nuclear accumulation 
in live cells [5]. One of the possible reasons for this is impermeability of nucleus membrane of live cells for ruthenium complexes. For a probe to be selective towards nucleus, among others it should have a cationic but also amphipathic character with the logarithm of water-octanol partition coefficient $\left(\log P_{\mathrm{o} / \mathrm{w}}\right)$ in the range -5 to 0 to facilitate crossing both cellular and nucleus membranes, high base strength $\left(\mathrm{p} K_{a}>10\right)$ to exclude localization in lysosome and finally a planar aromatic system for intercalation [6]. Some researchers have tried to optimize the polypyridyl ligands to reach selective accumulation in cellular DNA, e.g., by modification of dppz ligand with a nuclear targeting peptide chain [7-9] or with substituents increasing its hydrophobicity [2]. Recently the development of the ruthenium complexes toward their application in optical imaging of cells in hypoxia $[10,11]$ or as cytotoxic agents selectively activated in hypoxic cells [12] shows a new direction in design and great potency of this type of compounds. One of the most interesting research aspects is a dual imaging and therapeutic application of ruthenium polypyridyl complexes $[10,11,13]$. In this context an appropriate modification of polypyridyl ligands through the introduction of different substituents can tune cytotoxic and luminescent properties of ruthenium complexes.

The principal purpose of the present study is to show the multifaceted relationship between lipophilicity, protein interaction and luminescence properties of ruthenium(II) complexes affecting cell imaging and cytotoxic properties. The system chosen for this study as illustrated in Scheme 1, is the family of the ruthenium(II) complexes comprising two dip ligands and one bpy ligand, which, in turn, possesses various substituents at 4 and $4^{\prime}$ positions. The $\left[\mathrm{Ru}(\mathrm{dip})_{2}(\mathrm{bpy})\right]^{2+}, \quad\left[\mathrm{Ru}(\mathrm{dip})_{2}\left(\mathrm{CH}_{3} \text { bpy- } \mathrm{CH}_{3}\right)\right]^{2+}$ and $\left[\mathrm{Ru}(\mathrm{dip})_{2}\left(\mathrm{CH}_{3} \text { bpy-COO) }\right]^{+}\right.$(at $\mathrm{pH}>5$ the carboxylic group is deprotonated) are well known from the literature [14], we have recently published the synthesis of $\left[\mathrm{Ru}(\mathrm{dip})_{2}(\mathrm{bpy}-\mathrm{NitroIm})\right]^{2+}[11]$ while the formation of $\left[\mathrm{Ru}(\mathrm{dip})_{2}\left(\mathrm{CH}_{3} \text { bpy-DCU }\right)\right]^{2+}$ is described in this work.
These complexes have gained our attention since they are not expected to have intercalative properties as confirmed by previous work $[11,15]$ and these studies, therefore the cellular DNA is not postulated as their target. Moreover, the "light switch" effect in the presence of the DNA is not observed. This is in contrast to numerous studies for ruthenium polypyridyl complexes [3,16-18]. The selected substituents tune lipophilic and photophysical properties. To demonstrate the interplay between physicochemical/ photophysical properties and biological activity, we analyze the cytotoxicity and uptake of the studied compounds using 4T1 breast cancer cell line as well as the luminescence emitted by cells arising from ruthenium complex accumulation. We also show that the luminescence properties of these ruthenium complexes strongly depend on the interaction with albumin, which suggests that in cells the interaction with proteins can alter their imaging properties as well.

\section{Materials and methods}

Synthetic procedures

4,7-Diphenyl-1,10-phenanthroline (dip), 2,2'-bipyridine(bpy) and 4,4'-dimethyl-2,2'-bipyridine $\left(\mathrm{CH}_{3}\right.$ bpy- $\left.\mathrm{CH}_{3}\right)$ were purchased from Sigma-Aldrich. 4-carboxy-4'-methyl2,2'-bipyridine $\left(\mathrm{CH}_{3}\right.$ bpy-COOH$)$ and 4-[3-(2-nitro- $1 \mathrm{H}$-imidazol-1-yl)propyl]-2,2'-bipyridine (bpy-NitroIm) were prepared according to the published procedures [11, 19]. Ruthenium complexes of the type $\left[\mathrm{Ru}(\mathrm{dip})_{2} \mathrm{~L}\right] \mathrm{Cl}_{2}$ where $\mathrm{L}$ denotes bpy, $\mathrm{CH}_{3}$ bpy- $\mathrm{CH}_{3}, \mathrm{CH}_{3}$ bpy-COOH or bpy-NitroIm were prepared following the literature procedures $[11,19]$. The purity of the synthesized complexes was checked by HPLC and MS analyses.

$\left[\mathrm{Ru}(\mathrm{dip})_{2}\right.$ (1,3-dicyclohexyl-1-[4-carbonyl-(4'-methyl-2,2'bipyridyl) $]$-urea) $] \mathrm{Cl}_{2}$ ([Ru(dip) ${ }_{2}\left(\mathrm{CH}_{3}\right.$ bpy-DCU) $\left.] \mathrm{Cl}_{2}\right)$ was synthesized as follows. To a stirred solution of $\left[\mathrm{Ru}(\mathrm{dip})_{2-}\right.$ $\mathrm{CH}_{3}$ bpy-COOH] $\mathrm{Cl}_{2}(40 \mathrm{mg}, 0.038 \mathrm{mmol})$ in dry $\mathrm{CH}_{2} \mathrm{Cl}_{2}$
Scheme 1 The studied ruthenium complexes

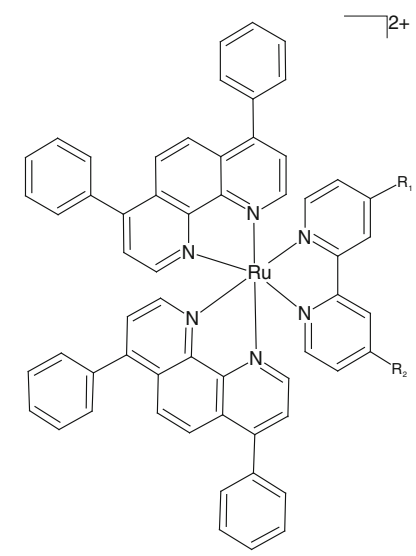

$\left[\mathrm{Ru}(\operatorname{dip})_{2}(\mathrm{bpy})\right]^{2+}: \mathrm{R}_{1}=\mathrm{R}_{2}=\mathrm{H}$
$\left[\mathrm{Ru}(\operatorname{dip})_{2}\left(\mathrm{CH}_{3} \text { bpy-CH}\right)\right]^{2+}: \mathrm{R}_{1}=\mathrm{R}_{2}=\mathrm{CH}_{3}$
$\left[\mathrm{Ru}(\operatorname{dip})_{2}\left(\mathrm{CH}_{3} \text { bpy-COO }\right)\right]^{+}: \mathrm{R}_{1}=\mathrm{CH}_{3}, \mathrm{R}_{2}=\mathrm{COO}^{-}$

[Ru(dip) $\left(\mathrm{CH}_{3} \text { by-COO) }\right]^{+}: \mathrm{R}_{1}=\mathrm{CH}_{3}, \mathrm{R}_{2}=\mathrm{COO}^{-}$

$\operatorname{Ru}(\operatorname{dip})_{2}\left(\mathrm{CH}_{3}\right.$ bpy-DCU $\left.)\right]^{2+}: \mathrm{R}_{1}=\mathrm{CH}_{3}, \mathrm{R}_{2}=\mathrm{O}_{0}$

$\left[\mathrm{Ru}(\operatorname{dip})_{2}(\text { bpy-NitroIm) }]^{2+}: \mathrm{R}_{1}=\mathrm{H}, \mathrm{R}_{2}=\right.$ 
(3 ml) with triethylamine $(0.15 \mathrm{ml}, 1 \mathrm{mmol})$, solution of $N, N$ '-dicyclohexylcarbodiimide $(16 \mathrm{mg}, 0.077 \mathrm{mmol})$ in dry $\mathrm{CH}_{2} \mathrm{Cl}_{2}(2 \mathrm{ml})$ was added. The mixture was stirred at room temperature for $48 \mathrm{~h}$ and then the solvent was removed under reduced pressure. The resulting solid was chromatographed on aluminium oxide using chloroform/methanol (50:1) solution as the eluent to afford final compound $(12 \mathrm{mg}$, $27 \%)$ as an orange solid. ${ }^{1} \mathrm{H}$ NMR $\left(600 \mathrm{MHz}, \mathrm{CDCl}_{3}\right): \delta$ 0.95-1.17 (m, 4H), 1.32-1.70 (m, 12H), 1.80 (m, 2H), 2.14 (bd, J 12.0, 2H), 2.63 (s, 3H), 3.33 (m, 1H), 4.31 (tt, J 3.4, 12.1, 1H), 7.42 (dd, J 1.0, 5.8, 1H), 7.49-7.62 (m, 1H), 7.65 (d, J 5.5, 1H), $7.71(\mathrm{~m}, 3 \mathrm{H}), 7.75(\mathrm{dd}, \mathrm{J} 1.6,5.8,1 \mathrm{H}), 7.78(\mathrm{~d}$, J 5.5, 1H), $7.88(\mathrm{~d}, \mathrm{~J} 5.4,1 \mathrm{H}), 7.95(\mathrm{~d}, \mathrm{~J} 5.5,1 \mathrm{H}), 8.07(\mathrm{~d}, \mathrm{~J}$ $5.9,1 \mathrm{H}), 8.09(\mathrm{~d}, \mathrm{~J} 5.5,1 \mathrm{H}), 8.16-8.25(\mathrm{~m}, 4 \mathrm{H}), 8.30(\mathrm{~d}, \mathrm{~J}$ $5.4,1 \mathrm{H}), 8.48(\mathrm{~d}, \mathrm{~J} 5.5,1 \mathrm{H}), 8.77(\mathrm{~d}, \mathrm{~J} 5.6,1 \mathrm{H}), 9.00(\mathrm{~s}, 1 \mathrm{H})$, $9.30(\mathrm{~s}, 1 \mathrm{H}), 9.49(\mathrm{~d}, \mathrm{~J} 8.1,1 \mathrm{H}) \mathrm{ppm} .{ }^{13} \mathrm{C} \mathrm{NMR}(150 \mathrm{MHz}$, $\left.\mathrm{CDCl}_{3}\right): \delta 21.42,25.05,25.16,25.46,26.01,30.71,31.04$, $31.45,31.64,50.96,55.35,123.11,125.75,125.84,126.21$, $126.38,126.40,126.64,126.91,127.45,127.84,128.75$, $128.88,128.90,129.06,129.12,129.23,129.28,129.39$, $129.64,129.70,129.74,129.78,129.97,130.03,135.23$, $135.31,135.37,135.44,146.12,147.62,147.98,148.54$, $148.58,149.01,149.30,149.34,149.55,150.91,151.09$, $151.15,151.41,151.92,152.73,153.71,154.18,155.97$, 157.41, 164.70 ppm. HRMS: calcd. for $\mathrm{C}_{73} \mathrm{H}_{64} \mathrm{~N}_{8} \mathrm{O}_{2} \mathrm{Ru}$ $\left[\mathrm{M}^{2+}\right]$ 593.2058, found 593.2092 (Fig. S1A). IR-ATR: 3354w, 3194w, 3054w, 2928m, 2853w, 2157w, 1971w, $1689 \mathrm{~m}, 1649 \mathrm{~s}, 1621 \mathrm{~s}, 1533 \mathrm{~m}$. HPLC: $t_{\mathrm{R}}=6.96 \mathrm{~min}$, HILIC, acetonitrile/ammonium acetate $(0.1 \mathrm{M})$, gradient from 95:5 to 1:1 (Fig. S1B).

Spectroscopic measurements

UV-Vis absorption spectra were recorded on a Perkin Elmer Lambda 35 spectrophotometer. Luminescence measurements were performed on a spectrofluorimeter Perkin Elmer LS55. The spectra were recorded at the room temperature in aqueous solution containing small amount of DMSO $(<0.008 \% \mathrm{v} / \mathrm{v})$. The emission spectra were recorded between 470 and $860 \mathrm{~nm}$ upon excitation at $463 \mathrm{~nm}$. The average of three scans was subjected to smoothing. For determination of the quantum yield of luminescence $(\Phi)$, aqueous solutions of $\left[\mathrm{Ru}(\mathrm{bpy})_{3}\right]^{2+}$ with a small amount of DMSO $(<0.008 \%$ v/v $)$ were used as standards $(\Phi=0.028$ [14] and 0.042 [20] for air-equilibrium and deoxygenated conditions, respectively). The spectra were recorded for ruthenium complexes at the concentration less than 0.05 absorbance unit at the excitation wavelength. Values were calculated according to the following equation [21]:

$\Phi=\Phi_{\text {ref }} \times\left[A_{\text {ref }} / A\right] \times\left[I / I_{\text {ref }}\right] \times\left[n^{2} / n_{\text {ref }}^{2}\right]$, where $I$ is the integrated intensity of luminescence, $A$ is the optical density, and $n$ is the refractive index, ref refers to the values for reference. The mean value from minimum three independent experiments was calculated.

The luminescence lifetime measurements were performed with a single photon counting technique using Fluorolog-3, Horiba Jobin Yvon. The excitation wavelength was set at $464 \mathrm{~nm}$ (NanoLed Diodes) and the average lifetime of luminescence was monitored at $621 \mathrm{~nm}$. Luminescence decays were collected with 1,000 counts in the peak. The instrument response functions were measured using a light scattering solution of Ludox (colloidal silica, Sigma-Aldrich). Experiments were conducted at room temperature. The DAS6 software (HORIBA Scientific) was used for deconvolution of the obtained decays and for calculation of the lifetime values. The quality of the fit was judged by the $\chi^{2}$ parameter (the goodness of fit evaluation). One-exponential fit was determined to be an optimal description of the obtained results for the ruthenium compounds.

\section{Protein-binding experiments}

The protein stock solution was prepared by dissolving human serum albumin (HSA) in water and its concentration was determined spectrophotometrically from the molar absorptivity of $4.4 \times 10^{4} \mathrm{~cm}^{-1} \mathrm{M}^{-1}$ at $280 \mathrm{~nm}$ [22-25]. The emission spectra were recorded between 305 and $500 \mathrm{~nm}$ upon excitation at $295 \mathrm{~nm}$ resulting in selective excitation of tryptophan residue of HSA. The average of three scans was subjected to smoothing and the fluorescence intensities were corrected due to dilution effects. Protein-binding experiments were conducted by measuring fluorescence spectra of protein solution $(1 \mu \mathrm{M})$ in the presence of different amounts of ruthenium compounds $(0-10 \mu \mathrm{M})$ in PBS buffer $\mathrm{pH} 7.4$ at $37{ }^{\circ} \mathrm{C}$. $\mathrm{Ru}$-protein solutions were allowed to incubate for $5 \mathrm{~min}$ before the emission spectra were recorded. The quantum yield and lifetime of luminescence for ruthenium complexes in the present of HSA $(1 \mu \mathrm{M})$ was measured using the same procedure as described for ruthenium complexes alone (the HSA/Ru-complex ratio is given in the figure caption).

\section{DNA-binding experiments}

Calf thymus deoxyribonucleic acid was purchased from Sigma-Aldrich and its stock solution was prepared by dissolving of solid DNA in water. DNA concentrations per nucleotide were determined by absorption spectroscopy using the molar absorption coefficient of $6,600 \mathrm{M}^{-1} \mathrm{~cm}^{-1}$ at the wavelength of $260 \mathrm{~nm}$ [4]. DNA-binding experiments were performed in $0.05 \mathrm{M}$ Tris/ $\mathrm{HCl}$ buffer ( $\mathrm{pH}$ 7.4) 
at $37{ }^{\circ} \mathrm{C}$. The absorption titration experiments were performed by using fixed concentration of ruthenium compound $(10 \mu \mathrm{M})$ until the absorption spectra did not change with increasing DNA concentration. Ruthenium-DNA solutions were allowed to incubate for $5 \mathrm{~min}$ before the spectra were recorded. The intrinsic DNA-binding constant was calculated from the following Eq. [4].

$\frac{[\mathrm{DNA}]}{\varepsilon_{\mathrm{a}}-\varepsilon_{\mathrm{f}}}=\frac{[\mathrm{DNA}]}{\varepsilon_{\mathrm{a}}-\varepsilon_{\mathrm{f}}}+\frac{1}{K_{\mathrm{b}}\left(\varepsilon_{\mathrm{b}}-\varepsilon_{\mathrm{f}}\right)}$,

where [DNA] is the total DNA concentration in nucleotides, $\varepsilon_{\mathrm{a}}, \varepsilon_{\mathrm{b}}, \varepsilon_{\mathrm{f}}$ are the apparent absorption coefficients of $\mathrm{A} /[$ ruthenium complex] of the MLCT absorption band at a given DNA concentration, fully bound and free ruthenium complex, respectively, $K_{\mathrm{b}}$ is binding constant.

The emission titration studies were performed by using fixed concentration of ruthenium compound $(3 \mu \mathrm{M})$. The DNA aliquots were added and after 5 min of incubation luminescence spectra upon excitation at $463 \mathrm{~nm}$ were measured. The average of three scans was subjected to smoothing and the luminescence intensities were corrected due to dilution effects.

\section{Determination of lipophilicity}

The lipophilicity of the ruthenium(II) complexes, which is referred to $\log P_{\mathrm{o} / \mathrm{w}}$ (n-octan-1-ol/water partition coefficient), was measured as following. Ruthenium complexes were dissolved in $n$-octan-1-ol (to mM concentration), then solutions were added to water and the mixtures were stirred sufficiently for partitioning at $25{ }^{\circ} \mathrm{C}$ for $24 \mathrm{~h}$. After that the mixtures were left for equilibration for another $2 \mathrm{~h}$. The concentration of the compounds in the water phase was measured spectrophotometrically and $P_{\mathrm{o} / \mathrm{w}}$ value was calculated according to the equation: $P_{\mathrm{O} / \mathrm{w}}=\frac{c_{\text {octano }}-c_{\text {water }}}{c_{\text {water }}}$, where $c_{\mathrm{octanol}}^{\text {before }}$ is an initial concentration of ruthenium complex, $c_{\text {water }}$ denotes final concentration in water [5]. The experiment was conducted in triplicates.

\section{Cell culture, cytotoxicity and apoptosis assays}

4T1 breast cancer cell line was cultured in RPMI-1640 (Gibco Invitrogen) with $10 \%$ fetal bovine serum (FBS, the bovine serum albumin is a major component), $1 \%$ penicillin and streptomycin and $0.2 \%$ fungizone. Cells were routinely cultured at $37^{\circ} \mathrm{C}$ in a humidified incubator in $5 \% \mathrm{CO}_{2}$ atmosphere. Cell viability was measured using Alamar Blue assay. Cells were seeded on 96-well plate with density of $10^{4}$ cells per $\mathrm{cm}^{2}$ and cultured for $24 \mathrm{~h}$ in medium with or without $2 \%$ serum. Then cells were incubated with various concentrations of ruthenium compounds for $24 \mathrm{~h}$ in the dark. All used ruthenium complexes were freshly diluted in DMSO and then added to the appropriate medium to obtain the applied concentrations. The final DMSO concentration was kept constant at $0.05 \%$ $(\mathrm{v} / \mathrm{v})$. Next cells were washed with PBS and incubated in AlamarBlue solution (21 times diluted in PBS) for $3 \mathrm{~h}$. Alamar Blue test is based on the reduction of blue and nonfluorescent subtract (resazurin) to a pink and highly fluorescent product (resorufin) by the alive cells. Extract mechanism of the reduction is still unknown, but it is postulated that reduction occurs by mitochondrial or cytoplasmic enzymes, such as NADH dehydrogenase or diaphorase. It is still not known whether this process occurs intracellularly, at the plasma membrane surface or just in the medium as a chemical reaction $[26,27]$. The cell viability was quantified at $605 \mathrm{~nm}$ using $560 \mathrm{~nm}$ excitation light (VICTOR 3V multilabel plate readers, PerkinElmer). Experiments were performed in triplicates and each experiment was performed at least three times to get the mean values \pm standard deviation. The viability was calculated with regard to the untreated cells control. The $\mathrm{IC}_{50}$ values were determined using Hill equation (Origin 9.0) [28]:

$y=y_{0}+\frac{\left(y_{100}-y_{0}\right)[c]^{H}}{\left[\mathrm{IC}_{50}\right]^{H}+[c]^{H}}$

The apoptosis was investigated using Hoechst 33258 staining method $[29,30]$. 4T1 cells were seeded into 96-well plate with a density of $2 \times 10^{4}$ cells per $\mathrm{cm}^{2}$ and cultured in the full medium for $24 \mathrm{~h}$. The medium was removed and replaced with medium containing various concentrations of the ruthenium complexes. Cells were incubated with compounds for $24 \mathrm{~h}$, then washed with icecold PBS, fixed with formalin $(4 \%)$. Cell nuclei were counterstained with Hoechst $33258(10 \mu \mathrm{g} / \mathrm{ml}$ in PBS) for $15 \mathrm{~min}$. Cells were then observed and imaged by an AxioVert 200M fluorescence microscope (Carl Zeiss).

\section{Ruthenium uptake measured by ICP-MS}

Cells were seeded on a 6-well plate with a density of $3 \times 10^{5}$ cells per $\mathrm{cm}^{2} .24 \mathrm{~h}$ after the incubation ruthenium complexes were added at $2 \mu \mathrm{M}$ concentration. Cells were incubated in medium without serum for $24 \mathrm{~h}$. After incubation cells were washed twice with PBS, detached by trypsin (trypsin/EDTA from Gibco) treatment, diluted in PBS and counted. Cells were digested in concentrated nitric acid overnight at room temperature and then diluted with water. The ruthenium content of the sample was 
determined by the inductively coupled plasma mass spectrometry (ICP-MS). Results were calculated as ruthenium concentration per cell (assuming the average volume of cell was $1.7 \mathrm{pL}[31])$.

Ruthenium uptake measured by flow cytometry

4T1 cells were seeded in a 24 -well plate with a density of $2 \times 10^{5}$ cells per $\mathrm{cm}^{2} .24 \mathrm{~h}$ after the seeding Ru(II) compounds were added at $2 \mu \mathrm{M}$ concentration and incubated for $24 \mathrm{~h}$ in medium with or without serum $(2 \%)$. Then cells were washed with PBS, detached by trypsin treatment and analyzed by BDLSR cytometer with an excitation wavelength of $488 \mathrm{~nm}$ and an emission wavelength of $575 \pm 13 \mathrm{~nm}$. The luminescence intensity of the control cells in the tested conditions was found to be negligible.

\section{Imaging}

4T1 cells were seeded on the black 96-well plate with a transparent bottom with a density of $10^{4}$ cells per $\mathrm{cm}^{2} 24 \mathrm{~h}$ prior the staining. Next cells were incubated with $1 \mu \mathrm{M}$ ruthenium complexes in medium with serum ( $2 \%)$ for $24 \mathrm{~h}$. After incubation cells were washed with PBS and images were acquired using an AxioVert 200M fluorescence microscope (Carl Zeiss). Illumination system Colibri with 4 LED excitation diodes (365, 470, 530 and $625 \mathrm{~nm}$ ) was applied as source of fluorescence and cube filter with excitation wavelengths 470 and $555 \mathrm{~nm}$, beam splitter $560 \mathrm{~nm}$, emission range $575-640 \mathrm{~nm}$ was used.

\section{Results and discussion}

Photophysical characterization of the ruthenium(II) complexes

The absorption spectra of all studied ruthenium compounds (Fig. S2) possess an arrow and intense band at $278 \mathrm{~nm}$ assigned to a spin allowed ${ }^{1} \mathrm{LC}\left({ }^{1} \pi \rightarrow \pi^{*}\right.$ bpy-R-centered $)$ transition, the shoulder at $314 \mathrm{~nm}$ originating from a ${ }^{1} \mathrm{LC}$ transition of phenanthroline moiety and two not well separated bands at $400-500 \mathrm{~nm}$ attributed to the spin allowed ${ }^{1}$ MLCT $d \rightarrow \pi^{*}$ transitions (assignment based on [32]). The molar absorption coefficients are presented in Table 1. The attachment of DCU moiety evidently decreases the intensity of the MLCT and LC bands while the other substituents at 4 and $4^{\prime}$ positions of the pyridine rings only slightly influence the energy and intensity of these bands.

The studied ruthenium complexes are found to be luminescent (Fig. S2) and they all express a shift of the emission maxima toward a longer wavelengths as well as a significant decrease in the quantum yield of luminescence with the respect to the parent complex $\left[\operatorname{Ru}(\operatorname{dip})_{2}(\text { bpy })\right]^{2+}$ (compare Table 1). The red shift is consistent with the withdrawing character of the attached substituents, which stabilize the lowest unoccupied molecular orbital of the bpy ligand, leading to a decrease in the energy of the MLCT level, responsible for the observed luminescence properties [14]. The reduction of luminescence quantum yield can be explained by "energy gap law", predicting an increase of nonradiative transitions for lower and lower energy gaps between the emitting level and the ground

Table 1 Photophysical properties for the ruthenium(II) complexes in air-equilibrated and deoxygenated aqueous solutions

\begin{tabular}{|c|c|c|c|c|c|c|c|}
\hline & \multicolumn{2}{|l|}{ Absorption } & \multicolumn{3}{|c|}{ Emission (air-equilibrated conditions) } & \multicolumn{2}{|c|}{ Emission (deoxygenated conditions) } \\
\hline & $\lambda_{\max }[\mathrm{nm}]$ & $\varepsilon\left[\mathrm{M}^{-1} \mathrm{~cm}^{-1}\right]$ & $\lambda_{\max }[\mathrm{nm}]$ & $\varphi$ & $\tau[\mathrm{ns}]$ & $\varphi$ & $\tau[\mu \mathrm{s}]$ \\
\hline$\left[\operatorname{Ru}(\operatorname{dip})_{2}(\mathrm{bpy})\right]^{2+}$ & $\begin{array}{l}278 \\
433 \\
458\end{array}$ & $\begin{array}{r}126,300 \\
27,400 \\
28,000\end{array}$ & 613 & $0.0367 \pm 0.0004$ & $760 \pm 10$ & $0.1245 \pm 0.0004$ & $2.51 \pm 0.01$ \\
\hline$\left[\mathrm{Ru}(\mathrm{dip})_{2}\left(\mathrm{CH}_{3} \text { bpy-CH} \mathrm{CH}_{3}\right)\right]^{2+}$ & $\begin{array}{l}279 \\
438 \\
461\end{array}$ & $\begin{array}{l}88,100 \\
19,000 \\
18,500\end{array}$ & 627 & $0.0254 \pm 0.0009$ & $690 \pm 10$ & $0.0778 \pm 0.0016$ & $2.23 \pm 0.01$ \\
\hline$\left[\mathrm{Ru}(\mathrm{dip})_{2}\left(\mathrm{CH}_{3} \text { bpy-COO }\right)\right]^{+}$ & $\begin{array}{l}279 \\
436 \\
463\end{array}$ & $\begin{array}{l}92,200 \\
22,100 \\
23,200\end{array}$ & 622 & $0.0226 \pm 0.0012$ & $530 \pm 10$ & $0.0429 \pm 0.0004$ & $1.02 \pm 0.01$ \\
\hline$\left[\mathrm{Ru}(\mathrm{dip})_{2}\left(\mathrm{CH}_{3} \text { bpy-DCU) }\right]^{2+}\right.$ & $\begin{array}{l}278 \\
440 \\
463\end{array}$ & $\begin{array}{l}67,400 \\
15,700 \\
16,200\end{array}$ & 641 & $0.0044 \pm 0.0002$ & $460 \pm 10$ & $0.0049 \pm 0.0002$ & $1.85 \pm 0.02$ \\
\hline$\left[\mathrm{Ru}(\mathrm{dip})_{2}(\mathrm{bpy}-\mathrm{NitroIm})\right]^{2+\mathrm{a}}$ & $\begin{array}{l}278 \\
433 \\
463\end{array}$ & $\begin{array}{l}88,400 \\
19,100 \\
19,700\end{array}$ & 621 & $0.0103 \pm 0.0004$ & $810 \pm 10$ & $0.0341 \pm 0.0004$ & $1.91 \pm 0.01$ \\
\hline
\end{tabular}

${ }^{a}$ Data taken from [11] 
Fig. 1 Fluorescence spectra of HSA in the present of different amount of $\left[\mathrm{Ru}(\mathrm{dip})_{2}\left(\mathrm{CH}_{3}\right.\right.$ bpy$\mathrm{DCU})]^{2+}$. Insert: the SternVolmer plot showing the influence of the increasing concentration of ruthenium complex on the fluorescence intensity of HSA at $\lambda_{\mathrm{em}}=358 \mathrm{~nm}$. Experimental conditions: $[\mathrm{HSA}]=1 \mu \mathrm{M}$; $[\mathrm{Ru}]=0-10 \mu \mathrm{M}$; PBS pH 7.4; $\lambda_{\mathrm{ex}}=295 \mathrm{~nm}, 37^{\circ} \mathrm{C}$

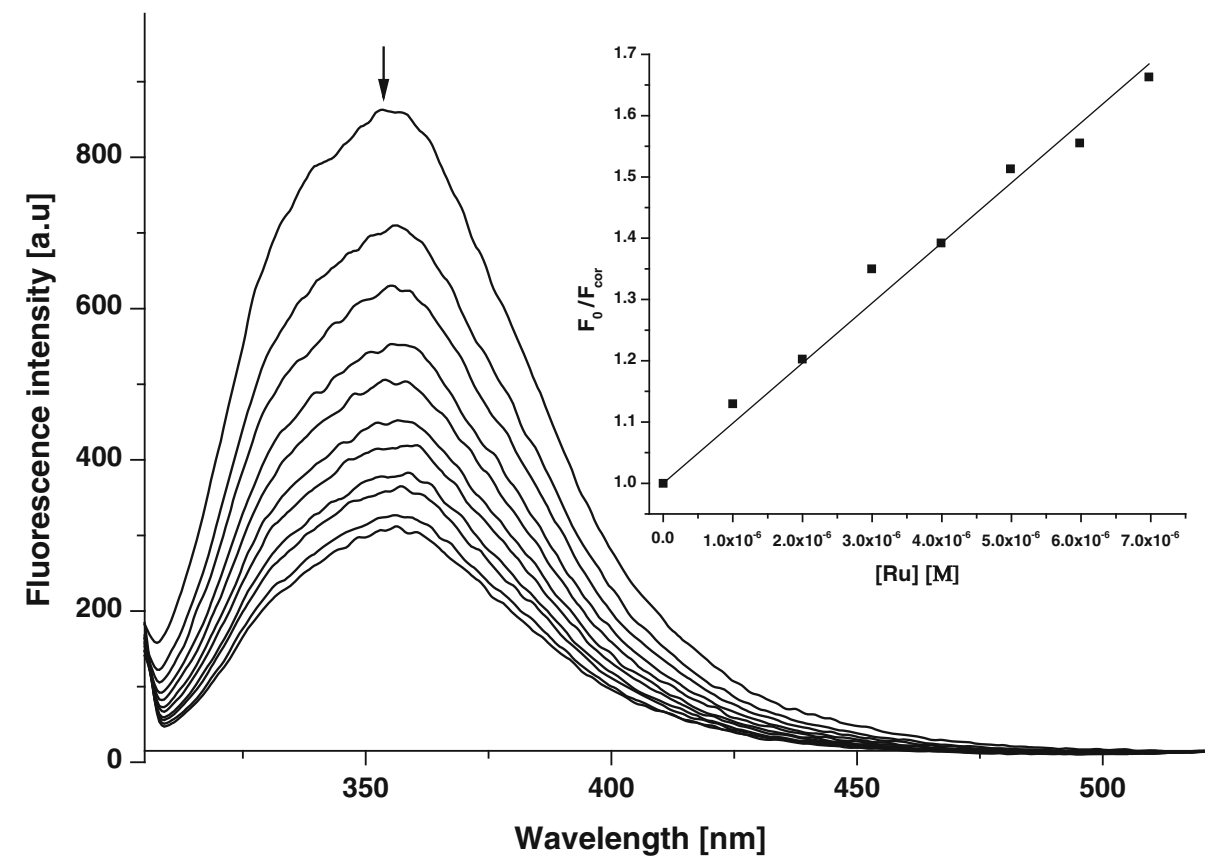

state [14]. Also developing a side chain of bpy ligand as in case of bpy-2-nitroIm and bpy-DCU can cause an enhancement of the complexes mobility leading to the increase of the vibration mode of relaxation. This is also reflected by almost twofold reduction in a luminescence lifetime for $\left[\mathrm{Ru}(\mathrm{dip})_{2}\left(\mathrm{CH}_{3} \text { bpy-DCU }\right)\right]^{2+}$ comparing to the parent complex. In contrast, for $\left[\mathrm{Ru}(\mathrm{dip})_{2}(\text { bpy-NitroIm) }]^{2+}\right.$ despite the decrease of the luminescence quantum yield, the luminescence lifetime increases probably due to interplay of the low-lying MLCT emitting levels and higherlying nonemissive metal-centered levels [14]. The luminescence parameters of the tested compounds strongly depended on molecular oxygen concentration (2-3 times higher in the deoxygenated solution), since quenching of the emission can occur by the diffusion-controlled interaction and energy transfer between the triplet excited state of the metal complex and triplet ground state of oxygen. This opens a possibility for application of ruthenium complexes as a luminescence probe for the optical imaging of physiological hypoxia [10]. Only in the case of $\left[\mathrm{Ru}(\mathrm{dip})_{2}\left(\mathrm{CH}_{3} \text { bpy-DCU }\right)\right]^{2+}$ oxygen does not influence strongly the quantum yield of luminescence, probably because of the increased complexes mobility and the vibration mode of relaxation caused by the expand ligand (bpy-DCU).

Influence of macro-biomolecules on luminescence parameters of the ruthenium complexes

There has been a growing interest in the investigations of the interactions between metal complexes and biomolecules, since these interactions can alter compounds stability, distribution and cytotoxicity [33]. Recently, we have shown that the presence of human serum albumin (HSA) greatly influences the luminescence parameters of $\left[\mathrm{Ru}(\mathrm{dip})_{2}(\mathrm{bpy}-\mathrm{NitroIm})\right]^{2+}[11]$. Similar effect but less pronounced (up to twofold enhancement) was observed for ruthenium complexes with one diimine and two phenathroline ligands with methyl groups substituted on position 3, 4,7 and 8 [34]. HSA is the most abundant protein in blood and exerts significant impact on drugs transport and toxicity [29], it can also serve as a model for examination of the interaction between drugs and proteins. Albumin displays strong emission peak at $356 \mathrm{~nm}$. Fluorescence is gradually decreased upon addition of ruthenium(II) polypyridyl complexes (as an example see Fig. 1).

The association constants for formation of adducts between ruthenium complexes and HSA were determined using spectrofluorimetric method [22, 35] (details are described in Supplementary Information) and are summarized in Table 2. Association constants for all complexes were found to be in the range of ca. $10^{5} \mathrm{M}^{-1}$ suggesting a moderate interaction between the investigated ruthenium complexes and albumin. The parent complex $\left[\mathrm{Ru}(\mathrm{dip})_{2}(-\right.$ bpy) $]^{2+}$ is characterized by the weakest interaction with albumin, while the attachment of an additional moiety for bpy ligand increases affinity of the complexes towards HSA, probably by increasing the lipophilicity or the hydrophobic surface of the complexes. The exception is complex with bpy-DCU ligand that is probably too bulky to achieve efficient binding.

The formation of adducts with albumin directly influences the luminescence parameters of the ruthenium complexes. The excitation of ruthenium complexes in the 
Table 2 The association constants for formation HSA-ruthenium(II) polypyridyl complex adducts

\begin{tabular}{ll}
\hline & $K_{\mathrm{a}}\left[\times 10^{5} \mathrm{M}^{-1}\right]$ \\
\hline$\left[\mathrm{Ru}(\text { dip })_{2}(\mathrm{bpy})\right]^{2+}$ & $0.78 \pm 0.02$ \\
{$\left[\mathrm{Ru}(\mathrm{dip})_{2}\left(\mathrm{CH}_{3} \text { bpy-CH }\right)\right]^{2+}$} & $1.24 \pm 0.06$ \\
{$\left[\mathrm{Ru}(\mathrm{dip})_{2}\left(\mathrm{CH}_{3} \text { bpy-COO }\right)\right]^{+}$} & $1.17 \pm 0.04$ \\
{$\left[\mathrm{Ru}(\text { dip })_{2}\left(\mathrm{CH}_{3} \text { bpy-DCU }\right)\right]^{2+}$} & $0.98 \pm 0.03$ \\
{$\left[\mathrm{Ru}(\mathrm{dip})_{2}(\text { bpy-NitroIm })\right]^{2+}$} & $1.10 \pm 0.06$ \\
\hline
\end{tabular}

presence of increasing amount of albumin at $463 \mathrm{~nm}$ leads to gradual increase of both the luminescence quantum yield as well as the average lifetime of emission as shown in Fig. 2. It is very likely that the interaction of ruthenium complexes with HSA leads to partial separation of the substituents attached to bpy ligand from $\mathrm{Ru}$ center by protein scaffold. In this way protein can prevent from quenching its luminescence by these moieties. Moreover, the hydrophobic interactions may intensify the observed emission. One can assume that similar interaction occurs inside the cells with other proteins and causes the enhancement of the luminescence of the ruthenium complexes. $\left[\mathrm{Ru}(\mathrm{dip})_{2}\left(\mathrm{CH}_{3} \text { bpy-DCU }\right)\right]^{2+}$ exhibits the largest increase in luminescence parameters upon addition of HSA: in PBS in the absence of addition $\varphi=0.0076$ while at $[\mathrm{HSA}] /[\mathrm{Ru}]=1, \varphi=0.0472$. This gives ca. ninefold increase in quantum yield of luminescence and makes HSA- $\left[\mathrm{Ru}(\mathrm{dip})_{2}\left(\mathrm{CH}_{3} \text { bpy-DCU }\right)\right]^{2+}$ adduct the most luminescent species among the studied protein-ruthenium complex adducts. Correspondingly, the luminescence average lifetime of ruthenium complexes upon addition of HSA changes in a similar way, showing 2- to 4-fold increase at $[\mathrm{HSA}] /[\mathrm{Ru}]=1$ (Fig. $2 \mathrm{~b}$ ).

The investigated ruthenium complexes have moderate DNA-binding constants (see Table 3, for experimental details see Supporting Information and Fig. S3). The intercalation of these complexes is not expected since unlike dppz ligand the dip ligands are too bulky to permit efficient intercalation or close contact while bpy ligands are too small to enable significant stacking [15] and the selected substituents do not influence strongly the binding properties. The type of interaction between $\left[\mathrm{Ru}(\mathrm{dip})_{2}(\mathrm{bpy}-\right.$ 2-nitroIm) $]^{2+}$ and DNA was thoroughly studied elsewhere [11]. Based on our previous research, we can suggest that electrostatic interaction and binding through a DNA groove are responsible for DNA-Ru interaction for tested complexes. The interaction with DNA causes unusual change in luminescence properties of these complexes (Fig. S4). Unlike ruthenium "light switch" complexes ([RuL 2 $\left.(\mathrm{dppz})]^{2+}\right)$, after addition of small excess of DNA luminescence of $\left[\mathrm{Ru}(\mathrm{dip})_{2}\left(\mathrm{R}_{1} \text { bpy- } \mathrm{R}_{2}\right)\right]^{2+/+}$ complexes decreases as a result of diffusion quenching by DNA [11].
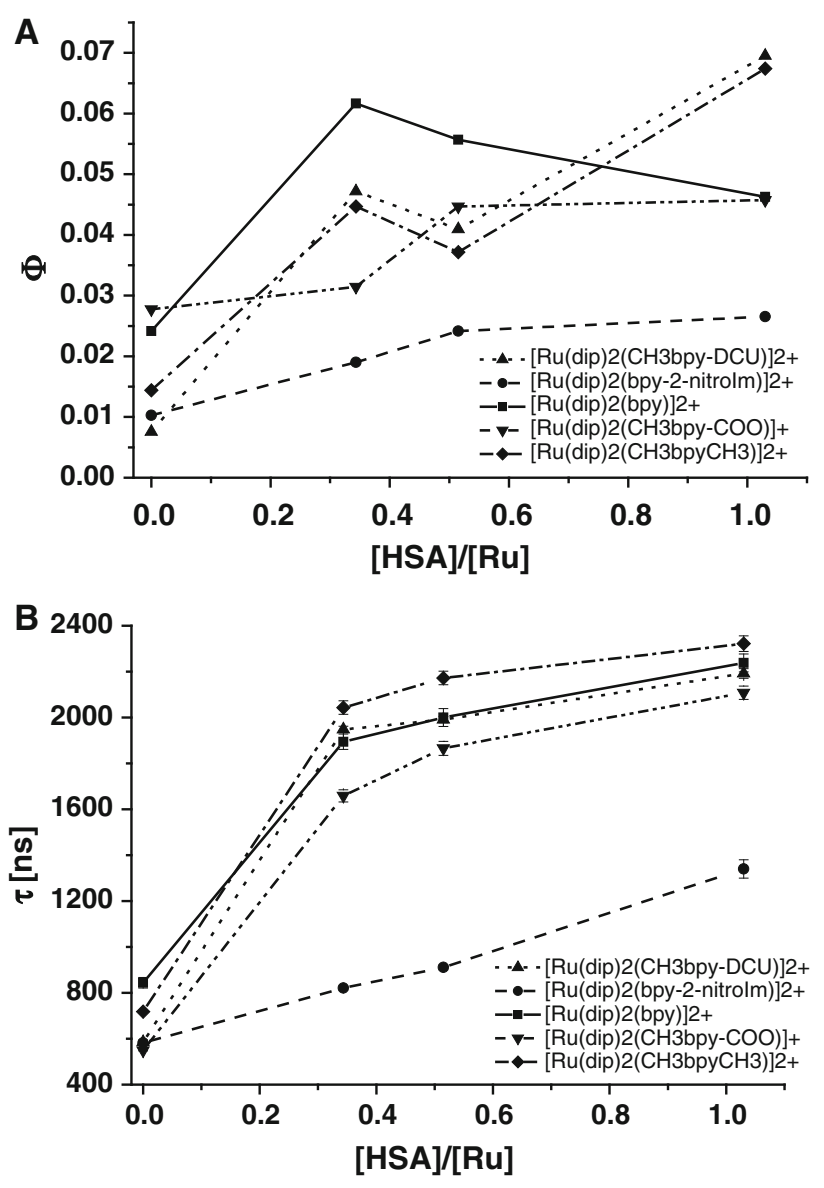

Fig. 2 The luminescence quantum yield (a) and the average lifetime of luminescence (b) of the studied ruthenium complexes for various $[\mathrm{HSA}] /[\mathrm{Ru}]$ ratios. Experimental conditions: $[\mathrm{HSA}]=1 \mu \mathrm{M}$, $[\mathrm{Ru}]=1-3 \mu \mathrm{M}$; PBS pH 7.4, excitation at $463 \mathrm{~nm}$

Interestingly, $\left[\mathrm{Ru}(\mathrm{dip})_{2}\left(\mathrm{CH}_{3} \text { bpy-DCU }\right)\right]^{2+}$ does not exhibit quenching of luminescence, but only small shift towards lower wavelengths (Fig. S4). It is reasonable to assume, that its weak luminescence properties arising from an increased mobility of the complex caused by the attached expand ligand (bpy-DCU) making it no longer sensitive toward quenchers like DNA or $\mathrm{O}_{2}$ (Table 1). Higher DNA/ $\mathrm{Ru}$ ratio( $>80$ excess of DNA) significantly increases of ruthenium complexes luminescence intensity (Fig. S4). This can be explained by reduction of their mobility and the vibration mode of relaxation, as well as the protection of the ruthenium complexes from quenching by water molecules due to the hydrophobic environment inside the DNA [36].

Lipophilicity of the ruthenium polypyridyl complexes

Lipophilicity is commonly described as the $n$-octan-1-ol/ water partition coefficient (expressed in $\log P_{\mathrm{o} / \mathrm{w}}$ ) of the compounds, which was determined by a shaking method. It 
Table 3 The binding constants for formation of DNA-ruthenium(II) polypyridyl complex adducts

\begin{tabular}{ll}
\hline & $K_{\mathrm{b}}\left[\times 10^{5} \mathrm{M}^{-1}\right]$ \\
\hline$\left[\mathrm{Ru}(\operatorname{dip})_{2}(\mathrm{bpy})\right]^{2+}$ & $0.82 \pm 0.01$ \\
{$\left[\mathrm{Ru}(\operatorname{dip})_{2}\left(\mathrm{CH}_{3} \text { bpy-CH}\right)\right]^{2+}$} & $0.53 \pm 0.03$ \\
{$\left[\mathrm{Ru}(\operatorname{dip})_{2}\left(\mathrm{CH}_{3} \text { bpy-COO }\right)\right]^{+}$} & $1.05 \pm 0.15$ \\
{$\left[\mathrm{Ru}(\operatorname{dip})_{2}\left(\mathrm{CH}_{3} \text { bpy-DCU }\right)\right]^{2+}$} & $0.60 \pm 0.02$ \\
{$\left[\mathrm{Ru}(\operatorname{dip})_{2}(\text { bpy-NitroIm })\right]^{2+}$} & $0.68 \pm 0.01$ \\
\hline
\end{tabular}

is well known that lipophilicity of the metal complexes is critical for their cellular selective uptake: cationic probes showing uptake in nuclei and lysosomes have $-5<\log P_{\mathrm{o} / \mathrm{w}}$ $<0$, while dyes with $0<\log P_{\mathrm{o} / \mathrm{w}}<5$ accumulate preferentially in mitochondria and endoplasmic reticulum [6]. The $\log P_{\mathrm{o} / \mathrm{w}}$ values of ruthenium(II) polypyridyl complexes are listed in Table 4. The additional substituents in bpy ligand increase lipophilicity of the ruthenium complexes. Among dicationic complexes $\left[\mathrm{Ru}(\mathrm{dip})_{2}\left(\mathrm{CH}_{3} \text { bpy-DCU }\right)\right]^{2+}$ is characterized by the highest $\log P_{\mathrm{o} / \mathrm{w}}$ value arising from the expanded substituent in bpy ligand, while for $\left[\mathrm{Ru}(\mathrm{dip})_{2}\left(\mathrm{CH}_{3} \text { bpy-COO }\right)\right]^{+}$the relatively high $\log P_{\mathrm{o} / \mathrm{w}}$ is caused by monocationic character of the complex. The literature data have demonstrated that positively charged ruthenium complexes show higher uptake than neutral one [15], at the same time monocationic species show higher uptake compared to the dicationic one [37]. However, the lipophilicity of the compound outweighs the influence of the number of positive charges [37]. The cellular uptake is at least partially controlled by lipophilicity, therefore this parameter can also influence the cytotoxicity of ruthenium complexes as well as the intensity of the observed luminescence signal.

\section{In vitro cytotoxicity}

The cytotoxicity of the ruthenium complexes was evaluated using $4 \mathrm{~T} 1$ breast cancer cell line. Cisplatin was used as a positive control. Ruthenium complexes can interact with proteins $[34,38]$, so cytotoxicity of the complexes was evaluated both in medium with or without serum. The $\mathrm{IC}_{50}$ values of the tested complexes are listed in Table 5.

Ruthenium polypyridyl complexes are found to be much more cytotoxic than cisplatin against $4 \mathrm{~T} 1$ cell line, ca. one order of magnitude. Among the tested compounds $\left[\mathrm{Ru}(\mathrm{dip})_{2}\left(\mathrm{CH}_{3} \text { bpy-DCU }\right)\right]^{2+}$ and $\left[\mathrm{Ru}(\mathrm{dip})_{2}\left(\mathrm{CH}_{3}\right.\right.$ bpy$\left.\left.\mathrm{CH}_{3}\right)\right]^{2+}$ were found to be the most toxic in the studied conditions. One of the possible explanations is the high lipophilicity of the former one and moderate liphophilicity and smaller size of the later one, which should facilitate their uptake. $\left[\mathrm{Ru}(\mathrm{dip})_{2}\left(\mathrm{CH}_{3} \text { bpy-COO }\right)\right]^{+}$is less cytotoxic despite the highest lipophilicity, this may be due to its
Table 4 Lipophilicity (log $P_{\mathrm{o} / \mathrm{w}}$ values) of the ruthenium(II) complexes

\begin{tabular}{ll}
\hline & $\log P_{\mathrm{o} / \mathrm{w}}$ \\
\hline$\left[\mathrm{Ru}(\text { dip })_{2}(\mathrm{bpy})\right]^{2+}$ & $0.328 \pm 0.026$ \\
{$\left[\mathrm{Ru}(\mathrm{dip})_{2}\left(\mathrm{CH}_{3} \text { bpy-CH}\right)\right]^{2+}$} & $0.484 \pm 0.046$ \\
{$\left[\mathrm{Ru}(\mathrm{dip})_{2}\left(\mathrm{CH}_{3} \text { bpy-COO }\right)\right]^{+}$} & $1.857 \pm 0.079$ \\
{$\left[\mathrm{Ru}(\text { dip })_{2}\left(\mathrm{CH}_{3} \text { bpy-DCU }\right)\right]^{2+}$} & $1.114 \pm 0.012$ \\
{$\left[\mathrm{Ru}(\text { dip })_{2}(\mathrm{bpy}-\mathrm{NitroIm})\right]^{2+}$} & $0.413 \pm 0.083$ \\
\hline
\end{tabular}

Table 5 The $\mathrm{IC}_{50}$ values of the ruthenium(II) complexes and cisplatin against $4 \mathrm{~T} 1$ cell line after $24 \mathrm{~h}$ of incubation in medium with or without serum $(2 \%)$

\begin{tabular}{lcr}
\hline & Without serum & \multicolumn{1}{c}{ With serum } \\
\hline$\left[\mathrm{Ru}(\mathrm{dip})_{2}(\mathrm{bpy})\right]^{2+}$ & $6.79 \pm 1.09$ & $13.56 \pm 1.75$ \\
{$\left[\mathrm{Ru}(\mathrm{dip})_{2}\left(\mathrm{CH}_{3} \text { bpy-CH}\right)\right]^{2+}$} & $4.90 \pm 0.30$ & $9.32 \pm 1.37$ \\
{$\left[\mathrm{Ru}(\mathrm{dip})_{2}\left(\mathrm{CH}_{3} \text { bpy-COO }\right)\right]^{+}$} & $8.66 \pm 1.47$ & $13.90 \pm 3.00$ \\
{$\left[\mathrm{Ru}(\mathrm{dip})_{2}\left(\mathrm{CH}_{3} \text { bpy-DCU }\right)\right]^{2+}$} & $4.71 \pm 0.18$ & $9.01 \pm 1.33$ \\
{$\left[\mathrm{Ru}(\mathrm{dip})_{2}(\text { bpy-NitroIm })\right]^{2+}$} & $10.64 \pm 1.05$ & $18.78 \pm 1.29$ \\
Cisplatin & $73.00 \pm 14.94$ & $59.81 \pm 8.32$ \\
\hline
\end{tabular}

lower accumulation as confirmed by uptake studies. The addition of serum containing as a major component bovine serum albumin to the incubation medium results in ca. twofold decrease in cytotoxicity (see Table 5). Likely the formed adducts between the tested ruthenium compounds and serum proteins are less accessible for the cells. Consequently, ruthenium accumulation may get less efficient. The range of cytotoxicity reduction correlates with the values of the protein-Ru association constants (Table 2). The same cytotoxic order for the studied ruthenium complexes was also found in human lung adenocarcinoma (A549) cell line as well as in two endothelial cell lines (murine lung microvascular endothelial and murine endothelial cells from AGM region from $10.5 \mathrm{dpc}$ embryos, details are presented in Supplementary information and in Table S1).

In order to clarify how ruthenium complexes affected cell growth, after treatment with compound cells were examined by fluorescence microscope. Representative images are shown in Fig. 3. 4T1 cells after incubation with ruthenium compounds show marked morphological sign of apoptosis, such as decreasing amount of detached cells, cells rounding and shrinkage [39]. To evaluate the nucleus morphological changes, cells were stained with Hoechst and analyzed by fluorescence microscopy. The untreated population of cells displays a homogenous morphology with round nuclei evenly stained with Hoechst. After treatment with ruthenium complexes, most of the cells display fragmented nuclei with densely stained nucleus granular bodies of chromatin (so-called "apoptotic 
Fig. 3 Effect of the ruthenium complexes treatment towards mammary cancer cells. a, c, e: DIC (differential interferential contrast), b, d, e: fluorescence labeling of the nuclei by Hoechst 33258 of the 4T1 cells after treatment by $8 \mu \mathrm{M}$ $\left[\mathrm{Ru}(\operatorname{dip})_{2}\left(\mathrm{CH}_{3} \text { bpy-DCU) }\right]^{2+}(\mathbf{c}\right.$ d) or $\left[\operatorname{Ru}(\operatorname{dip})_{2}(\mathrm{bpy})\right]^{2+}(\mathbf{e}, \mathbf{f})$, for $24 \mathrm{~h}$. a and b show control cells
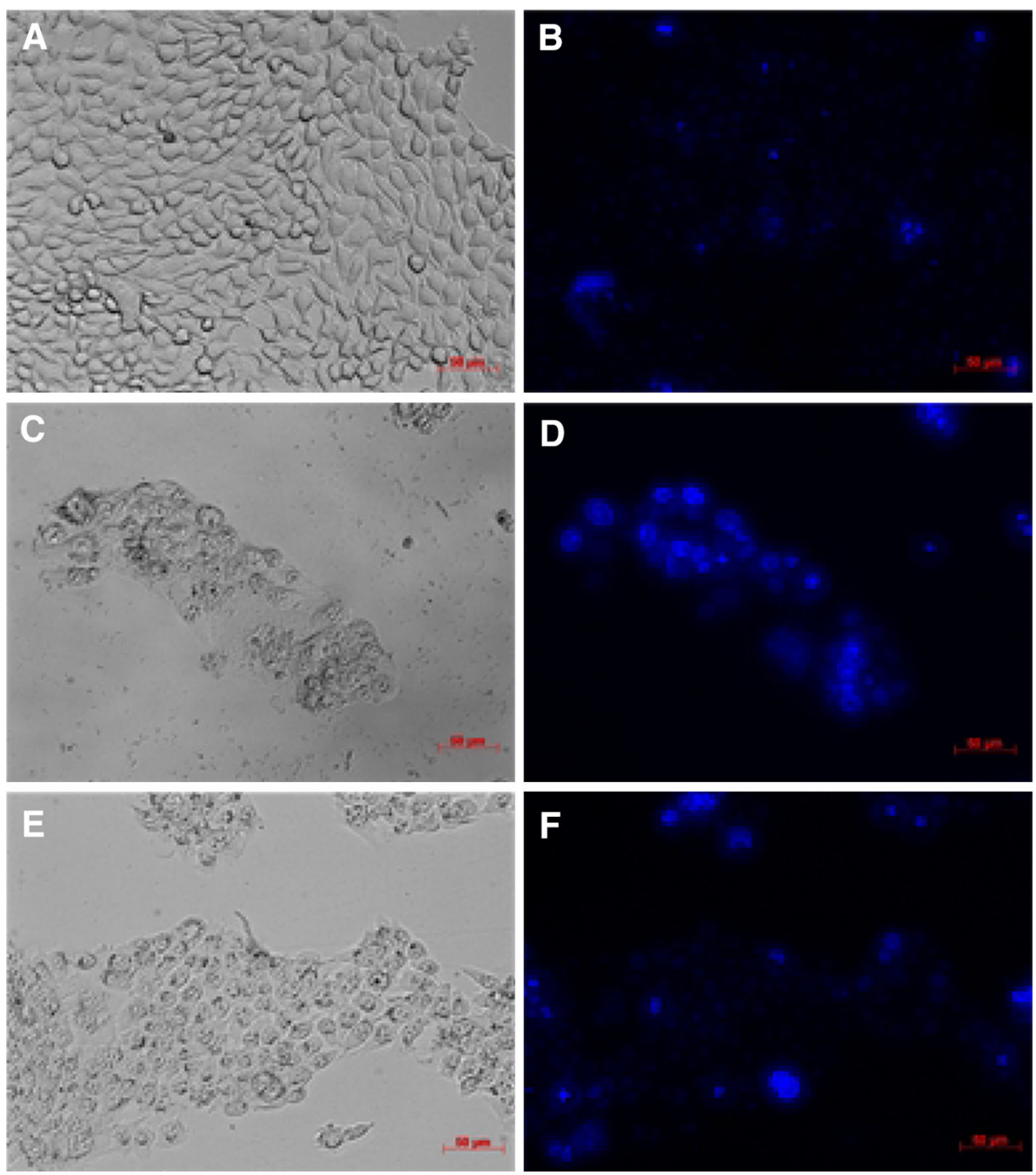

bodies") [29]. The results suggest that cytotoxic effect of ruthenium complexes is based at least partially on their pro-apoptotic properties.

\section{Cellular uptake studies by ICP-MS}

To quantify the concentration of ruthenium accumulated inside the 4T1 cells, the ICP-MS measurements were used. The uptake was determined for the sub-lethal dose of ruthenium compounds to evaluate the ability of the tested complexes to internalize into live cells. The absolute values of ruthenium concentration found in cells strongly depend on applied experimental conditions [40], thus the obtained results shown in Fig. 4 are presented in relation to $\left[\mathrm{Ru}(\operatorname{dip})_{2}\left(\mathrm{CH}_{3} \text { bpy-DCU }\right)\right]^{2+}$ that exhibits the highest accumulation. The actual values of the accumulated ruthenium concentration vary from 130

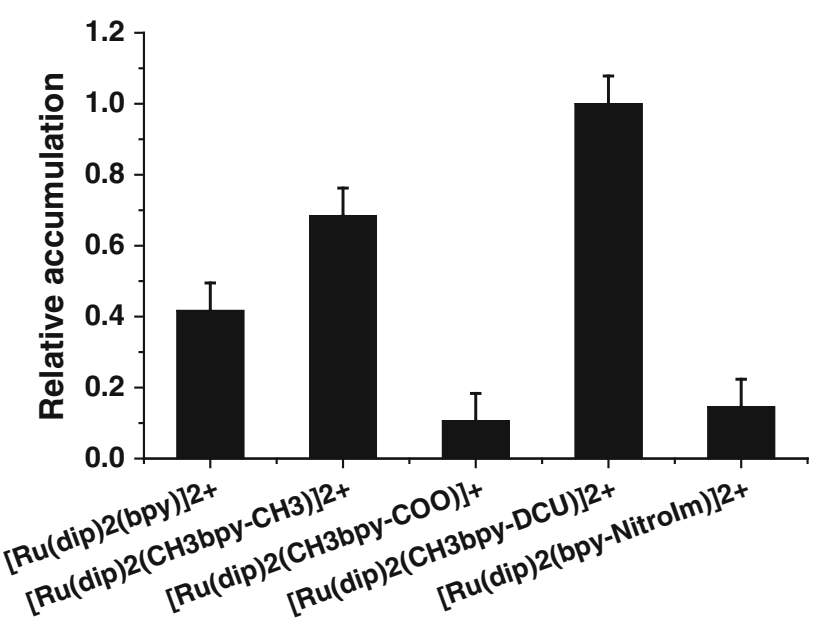

Fig. 4 Relative ruthenium accumulation in 4T1 cell line in a single cell determined by ICP-MS. Experimental conditions: [Ru-complex $]=2 \mu \mathrm{M}, 24 \mathrm{~h}$ incubation in the darkness 
to $1,200 \mu \mathrm{M}$ (Fig. S5) and it correlates with previously reported ICP-MS measurement of ruthenium complexes uptake [31]. The rise of the accumulation for dicationic ruthenium complexes correlates with their increased lipophilicity. Such relationship has been already reported [41]. The monocationic $\left[\mathrm{Ru}(\operatorname{dip})_{2}\left(\mathrm{CH}_{3} \text { bpy-COO }\right)\right]^{+}$ expresses much smaller accumulation than the rest of the studied complexes despite having the highest $\log P_{\mathrm{o} / \mathrm{w}}$ value. The charge of the compound displays a stronger influence than lipophilicity on ruthenium accumulation. This can arise from a possible facilitated transport of ruthenium polypyridyl complexes into cells via passive diffusion due to membrane potential [31]. The greater uptake the higher cytotoxicity suggests that internalization of the ruthenium complexes is required for their biological activity.

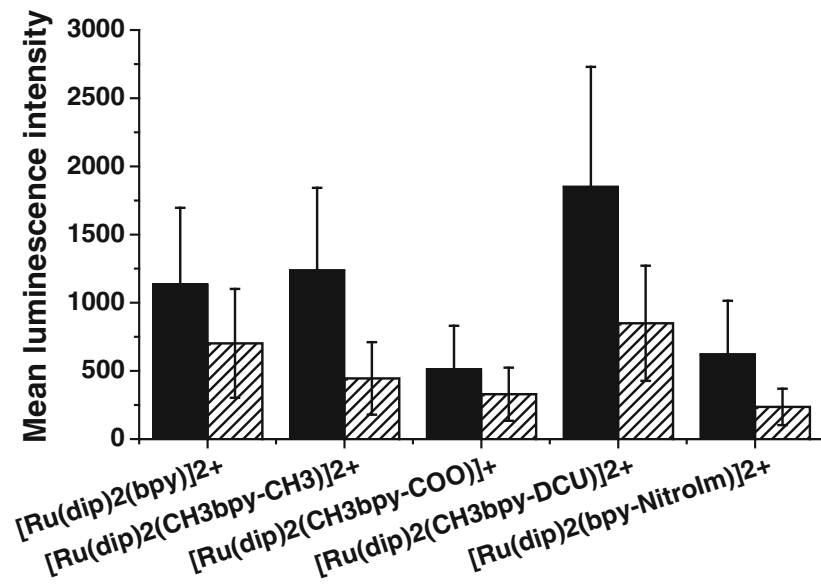

Fig. 5 Mean luminescence intensity of 4T1 cell lines incubated with ruthenium compounds measured by flow cytometry (filed incubated without serum, dashed incubated with serum). Experimental conditions: $[\mathrm{Ru}$-complex] $=2 \mu \mathrm{M}, 24 \mathrm{~h}$ of incubation in medium without or with serum $(2 \%)$
Cell luminescence upon treatment by ruthenium complexes

The uptake of the tested ruthenium complexes by 4T1 cells was also monitored using flow cytometry (Fig. S6). It must be noted that the light emission by the cells was not proportional to the amount of ruthenium incorporated inside cells since the luminescence quantum yield for various ruthenium complexes is different. Furthermore, the luminescence of ruthenium complexes is substantially influenced by the interaction with proteins. The observed luminescence signal (shown in Fig. 5) combines both the ability of the compounds to cross the cell membrane and the luminescence intensity emitted after interaction with cytoplasmic molecules and organelles. This method is adequate for an evaluation of the cell staining capacity by ruthenium complexes. $\left[\mathrm{Ru}(\mathrm{dip})_{2}\left(\mathrm{CH}_{3} \text { bpy-DCU }\right)\right]^{2+}$ provided the highest luminescence of $4 \mathrm{~T} 1$ cells. This complex is characterized by the smallest quantum yield of luminescence, but due to its interaction with protein the quantum yield greatly increases and its high lipophilicity intensifies its uptake. In general, for all the studied complexes the order of luminescence expressed by cells correlates with the cellular uptake determined by ICP-MS method as well as the cytotoxicity data. When the incubation of ruthenium complexes with cells was carried out in medium supplemented with serum, the cells expressed smaller luminescence intensity (see Fig. 5). This further confirms that the access of the ruthenium complexes to cells is lower, probably due to formation of adduct with proteins. Similar results have been obtained for endothelial MLuMEC cells (Supplementary Information Fig. S7).

Analyzing the staining pattern of live cells for the studied ruthenium complexes, no significant differences between each other is found (Fig. 6; Fig. S8), only the intensity of the staining is altered. This suggests that the place of accumulation of ruthenium complexes is determined by two dip ligands attached to each studied
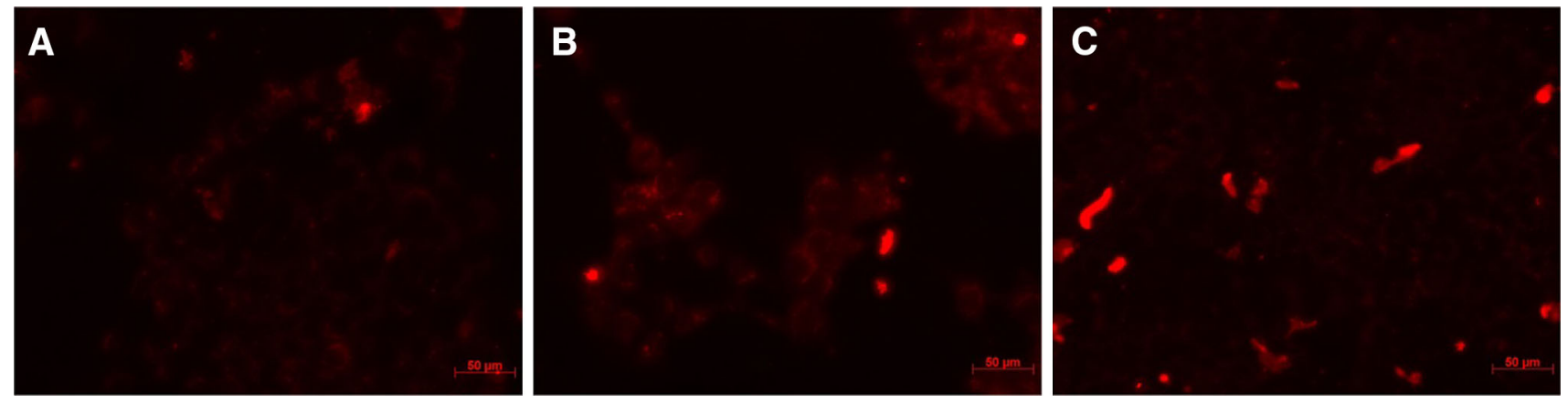

Fig. 6 Fluorescence images of cells incubated with $1 \mu \mathrm{M}\left[\mathrm{Ru}(\operatorname{dip})_{2}\left(\mathrm{CH}_{3} \mathrm{bpy}-\mathrm{DCU}\right)\right]^{2+}(\mathbf{a}),\left[\mathrm{Ru}(\mathrm{dip})_{2}(\mathrm{bpy})\right]^{2+}(\mathbf{b}),\left[\mathrm{Ru}(\operatorname{dip})_{2}(\mathrm{bpy}-\mathrm{NitroIm})\right]^{2+}$ (c) for $24 \mathrm{~h}$ 
complex. Cytoplasm is marked homogeneously with edge of the nucleus (mitochondria/endoplasmic reticulum) pointed out. No staining in the nucleus is observed confirming no incorporation in the DNA.

\section{Conclusions}

We have shown for a series of complexes $\left[\mathrm{Ru}(\mathrm{dip})_{2}\left(\mathrm{R}_{1}\right.\right.$ bpy$\left.\left.\mathrm{R}_{2}\right)\right]^{2+/+}$ that the higher luminescence parameters measured in aqueous solution do not directly correspond to the best cell staining properties. It is a combined effect of the luminescence expressed in cellular environment and the extent of its accumulation. For all studied complexes the interaction with human serum albumin results in pronounced increase of quantum yield and lifetime of luminescence. This phenomenon can be called "light switch" effect and for the studied complexes is observed only in the presence of albumin while DNA induces minor changes in their luminescence. As the intracellular protein content is high (ca. $50-400 \mathrm{mg} / \mathrm{ml}$ ) we can expect that similar effect is taking place. Therefore, while designing cellular probes it is necessary to take into account not only the luminescence parameters of a single substance, but also the possible resulting adducts with biomacro molecules. The $\left[\mathrm{Ru}(\mathrm{dip})_{2}\left(\mathrm{CH}_{3} \text { bpy-DCU }\right)\right]^{2+}$ regardless of its weakest luminescence parameters displays the best staining properties. Additionally, the lipophilicity and complex charge determine the level of its uptake which explains its cytotoxicity and imaging properties. The mechanism of action of these type of complexes remains still unknown, but our preliminary data point out that they can induce the apoptosis.

Acknowledgments Financial support from the National Science Center (Grant No. N N204 247340) is acknowledged. The research was carried out with equipment purchased with financial support from the European Regional Development Fund within the framework of the Polish Innovation Economy Operational Program (contract no. POIG.0 2.01.00-12-0 23/08). O.M. acknowledges the financial support from the project Interdisciplinary $\mathrm{PhD}$ Studies "Molecular sciences for medicine" (co-financed by the European Social Fund within the Human Capital Operational Programme). The authors gratefully acknowledge Wiesław Knap for performing the ICP-MS experiments.

Open Access This article is distributed under the terms of the Creative Commons Attribution License which permits any use, distribution, and reproduction in any medium, provided the original author(s) and the source are credited.

\section{References}

1. Friedman AE, Chambron J-C, Sauvage J-P, Turro NJ, Barton JK (1990) J Am Chem Soc 112:4960-4962

2. Gill MR, Derrat H, Smythe CGW, Battaglia G, Thomas JA (2011) Chembiochem 12:877-880
3. Gao F, Chao H, Zhou F, Yuan YX, Peng B, Ji LN (2006) J Inorg Biochem 100:1487-1494

4. Srishailam A, Kumar YR, Gabra NMD, Reddy PV, Deepika N, Veerababu N, Satyanarayanna S (2013) J Fluoresc 23:897-908

5. Puckett CA, Barton JK (2007) J Am Chem Soc 129:46-47

6. Horobin RW, Stockert JC, Rashid-Doubell F (2006) Histochem Cell Biol 126:165-175

7. Puckett CA, Barton JK (2010) Bioorg Med Chem 18:3564-3569

8. Puckett CA, Barton JK (2009) J Am Chem Soc 131:8738-8739

9. Blackmore L, Moriarty R, Dolan C, Adamson K, Forster RJ, Devocelle M, Keyes TE (2013) Chem Commun 49:2658-2660

10. Komatsu H, Yoshihara K, Yamada H, Kimura Y, Son A, Nishimoto S, Tanabe K (2013) Chem Eur J 19:1971-1977

11. Mazuryk O, Maciuszek M, Stochel G, Suzenet F, Brindell M (2014) J Inorg Biochem 134:83-91

12. Yadav A, Janaratne T, Krishnan A, Singhal SS, Yadav S, Dayoub AS, Hawkins DL, Awasthi S, MacDonnell FM (2013) Mol Cancer Ther 12:643-653

13. Chen Y, Qin M-Y, Wang L, Chao H, Ji L-N, Xu A-L (2013) Biochimie 95:2050-2059

14. Waern JB, Desmarets C, Chamoreau L, Amouri H, Barbieri A, Sabatini C, Ventura B, Barigelletti F (2008) Inorg Chem 47:3340-3348

15. Lamoureux M, Seksek O (2010) J Fluoresc 20:631-643

16. Zeglis BM, Pierre VC, Barton JK (2007) Chem Commun 44:4565-4579

17. Tan LF, Shen JL, Chen XJ, Liang XL (2009) DNA Cell Biol 28:461-468

18. Gill MR, Thomas JA (2012) Chem Soc Rev 41:3179-3192

19. Caspar R, Cordier C, Waern JB, Guyard-Duhayon C, Gruselle M, Le Floch P, Amouri H (2006) Inorg Chem 45:4071-4078

20. Nair RB, Cullum BM, Murphy CJ (1997) Inorg Chem 36:962-965

21. Lakowicz JR (2006) Principles of fluorescence spectroscopy. Springer, New York

22. Mazuryk O, Niemiec E, Stochel G, Gillaizeau I, Brindell M (2013) J Lumin 140:51-56

23. Lu X-L, Fan J-J, Liu Y, Hou A-X (2009) J Mol Struct 934:1-8

24. Feroz SR, Mohamad SB, Bakri ZSD, Malek SNA, Tayyab S (2013) Plos One 8:e76067

25. Carta G, Jungbauer A (2010) Protein chromatography: process development and scale-up. Wiley-VCH, Federal Republic of Germany

26. O'Brien J, Wilson I, Orton T, Pognan F (2000) Eur J Biochem 267:5421-5426

27. Borra RC, Lotufo MA, Gagioti SM, Barros FDM, Andrade PM (2009) Braz Oral Res 23:255-262

28. Weyermann J, Lochmann D, Zimmer A (2005) Int J Pharm 288:369-376

29. Liu Y, Yu Q, Wang C, Sun D, Huang Y, Zhou Y, Liu J (2012) Inorg. Chem. Comm. 24:104-109

30. Tan C, Hu S, Liu J, Ji L (2011) Eur J Med Chem 46:1555-1563

31. Puckett CA, Barton JK (2008) Biochemistry 47:11711-11716

32. Juris A, Balzani V, Barigelletti F, Campagna S, Belser P, Vonzelewsky A (1988) Coord Chem Rev 84:85-277

33. Fanali G, di Masi A, Trezza V, Marino M, Fasano M, Ascenzi P (2012) Mol Asp Med 33:209-290

34. Rajendiran V, Palaniandavar M, Periasamy VS, Akbarsha MA (2012) J Inorg Biochem 116:151-162

35. Mazuryk O, Kurpiewska K, Lewinski K, Stochel G, Brindell M (2012) J Inorg Biochem 116:11-18

36. Sun B, Wang YC, Qian C, Chu J, Liang SM, Chao H, Ji LN (2010) J Mol Struct 963:153-159

37. Schafer S, Ott I, Gust R, Sheldrick WS (2007) Eur J Inorg Chem 2007:3034-3046 
38. Mazuryk O, Suzenet F, Kieda C, Brindell M, (2014) in preparation

39. Chen Y, Lu B, Yang Q, Fearns C, Yates J, Lee JD (2009) Cancer Res 69:3713-3720
40. Egger AE, Rappel C, Jakupec MA, Hartinger CG, Heffeter P, Keppler BK (2009) J Anal At Spectrom 24:51-61

41. Yu HJ, Chen Y, Yu L, Hao ZF, Zhou LH (2012) Eur J Med Chem 55:146-154 